\title{
SEARCHING FOR THE MANAGERIAL IMPLICATIONS IN ITALIAN AUTONOMOUS MUSEUM. WHAT ARE THE PERSPECTIVES AND BARRIERS?
}

\author{
Marianna Marzano ${ }^{1}$ \\ Monia Castellini
}

DOI: https://doi.org/10.31410/ITEMA.2019.73

\begin{abstract}
The Italian public museums have been involved by a Reformation that has changed their status from non-autonomous museums to autonomous museums (Decree 171/2014 by the Ministry of Cultural Heritage and Tourism). This change has had significant implications for the Italian museums, introducing new managerial practices that has an impact on the system museum overall. Usually, public museums are supported by public funds. The autonomy could be a first step in overcoming critical issues that could be found in museums, aimed at supporting strategic and decision-making objectives and evaluating performance.
\end{abstract}

Often, the literature has revealed that the lack of managerial cultural is due to barriers (ideological, technical and, organizational) that do not permit the development of managerial practices.

Through a documental analysis, it has been investigated the main management innovations and its accounting implications. Consequently, the degree of compliance of the museums with del legislator's request has been analysed.

Keywords: Management, Accounting, Performance, Italian Museums.

\section{INTRODUCTION}

$\mathrm{O}$ ver the years the Italian cultural sector and, specifically the museum sector, has been indirectly affected by the reform processes that have involved the national public system driven by the introduction of company logics attributable to the New Public Management paradigm (Hood, 1991; Guthrie and Parker, 1990; Osborne and Gaebler, 1992; Cepiku et al., 2008). The process of change for the Italian museum system was characterized by two main lines of intervention. One is the reform path that involved the national public system as a whole and therefore also the museum organizations (as peripheral realities, not autonomous, of the central administration); the second concerns the introduction of ad hoc regulatory interventions however limited in their scope of managerial change (Marzano and Castellini, 2018).

Over the last five years, however, the Italian cultural sector has also undergone a specific and targeted reform process aimed at implementing managerial logic, principles, and tools in line with the NPM assumptions (Zan, 1999; Bonini Baraldi, 2007), oriented towards the pursuit of institutional goals.

The studies on the museums have underlined many features that characterize this field. The first limit has been identified in the dependence totally on public funding that has required the in-

\footnotetext{
1 Department of Economics and Management - University of Ferrara - Ferrara, Via Voltapaletto 11 - 44124 Ferrara (FE), Italy

2 Department of Economics and Management - University of Ferrara - Ferrara, Via Voltapaletto 11 - 44124 Ferrara (FE), Italy
} 
tensification of the communicative dimension to find external resources. The problem of funds (Donato, 2013) is accentuated with the reduction and resizing of public financial resources. Another element that has emerged from the sector is the poor propensity to results and the inadequate attention to the planning and definition of objectives to be pursued in terms of quality and quantity, the development of an organizational culture oriented to results and control, as noted in other sectors of public administration.

The main concerns the lack of autonomy and, consequently, the subordination from the central structure in terms of decision-making, organization, and economic-financial management.

With particular regard to this last aspect, the absence of a system of autonomy in this sense has been significant, which has conveyed the museums belonging to the public towards an expense reporting system.

Autonomy has been declined at least in three main aspects: the first concerned the introduction for museums of an own accounting system, moving away from management (no longer in economy) that saw the processing of financial information in the budget of the membership body. The second refers to the introduction of both financial and economic-asset accounting; the third relates to the management of resources deriving from revenues for ticketing and other activities (donations, rents, etc.) through the introduction of a treasury and cash service at a credit institution.

Also, in this context, as it happened in the past for other sectors of the Italian public system and not only, it may be necessary to intervene to analyse and understand the real state of the art and degree of implementation of the reform started with the decree 171/2014.

The main studies are been implemented in a context where did not exist the autonomy, giving evidence about the importance to implement the strategies and how the museums needed for managerial tools to be managed. Actually, the studies are not compared to the economic-financial autonomy and its degree of application within the museums. If the autonomy and the implementation of accounting system is an informative tool to support for the management, consequently it is important firstly to investigate the degree of compliance of the museums with the legislator's requests, answering to the following research question:

- Regarding the accounting provisions defined by the Legislator, what is the degree of regulatory compliance by autonomous state museums?

It has been conducted a documental analysis of 32 autonomous museums, searching the budget and final balances during the period 2016-2019.

The study is structured in six sections: following the introduction, there is the theoretical background on the focus of the study on the museums and the Italian reform of the Ministry of Cultural Heritage. The third section explains the research framework, the fourth develops the analysis and, finally, there are the final considerations.

The work permits us to understand the implications of the reform analyzing the reform according to the implications of the autonomy and applications of accounting practices required. The study should give also a contribution to the literature on the effects of autonomy and accounting in the cultural sector. On the other hand, the study could give a contribution to the practitioners to understand the point of weakness and cope with the problem of the relevance of guidelines. 


\section{THEORETICAL BACKGROUND.}

\subsection{Museums and autonomy: which implications for performance and accounting.}

As underlined by the researchers, the influence of New Public Management reforms has redefined the management of public sector to reinvent the governance of the public administration and to translate some practices derived by the private sector within the public field (Hood, 1991; Osborne and Gaebler, 1992; Cepiku et al., 2008). Sometimes, it happens a gap between the goal of the reforms and the conditions to apply the normative requirements in practice (Pavan and Reginato, 2004) and, the troubles to introduce managerial practice within the public administration (Ongaro and Valotti, 2008). At the same time, among the sectors that are influenced by this new paradigm, it emerges the scenario of cultural heritage, introducing the concept of management in this field (Thompson, 2001; Zan, 1999, 2003).

This closeness of cultural heritage to economic and managerial principles had generated a debate between the experts of both areas (Bourdie, 1992). The researchers have focused on the interests of the studies on the performance of museums, strategies and, the accounting systems to favor the introduction of a control and management process.

Most museums were not capable to implement managerial strategies for two main reasons highlighted by the studies; the first because they aim to perceive social mission and do not consider the economic sustainability (Migale, 2001), the second reason subsists because they are based on the public funds (Sibilio Parri, 2004).

The introduction of accounting has been considered as an element to use for the performance measurement that could introduce improvement through management and control (Chirieleison, 1999). The introduction of accounting within the public museums is linked to the reform of the public sector and to the level of autonomy granted to them to do not depend on the central administrative structure. Indeed, the reform of the public sector, in general, has noted the role of autonomy, because the condition of autonomy permits to introduce financial and economic autonomy.

Autonomy, so that it can be considered as such and offer a capacity for action and a certain degree of responsibility, must allow the independence of an organization from the point of view: of decision-making choices (autonomy of will), of the attribution of possession of the collections or properties (property autonomy), monitoring of inflows and outflows of monetary resources (financial autonomy), the ability on the one hand to find resources and on the other to manage them adequately (economic autonomy) (Chirieleison, 2002). As highlighted, for cultural organizations in general, the degree of autonomy is in relation to the form of management adopted (Del Sordo et al., 2012), i.e. the legal framework determines the level of autonomy, the degree of accountability and the documentation accounting that must be provided in compliance with the requirements of the Legislator.

The autonomy granted to the public museums has been seen as a first element that hinders the management, but as noted by Chatelain-Ponroy (2001) there are other kinds of obstacles such as ideological, technical, and organizational.

Paulus (2003), analysing how French and American museums measure the performance, sustains the relevance of factors such as effectiveness and efficiency to manage the museums. 
Indeed, the analysis of the characteristics of scenario permits to select the methods to manage the museums according to the objectives and approaches adopted by museums (Dainelli, 2003). Turbide and Laurin (2009) reveal the importance to measure the results but using a multidimensional approach that takes into consideration the features of the cultural organizations such as the resources, cultural assets and, collectivity.

Gstraunthaler and Piber's (2012) research has shown that accounting data has often been considered synonymous with quality and performance. Nevertheless, this is an incomplete view because, as they show, quantitative data must be integrated with qualitative ones. According to this research, the accounting data support the selection of activities, actions and key figures that allow the strategic objectives to be achieved.

In Italy, the studies about the introduction of accounting system within the public museums are still few, and they are the explorative studies (Gori and Fissi, 2012). Until 2014, the year of introduction of the new reform of cultural heritage, with the exception of private museums, the Italian public museums have not an accounting system because depending on the central administration.

\subsection{Museum's reform and economic \& financial autonomy.}

The Franceschini Reform has brought about a structural change, with a top-down approach, substantially intervening on the entire structure of the Ministry, in order to respond to the expenditure revision logic, implementing an organizational decentralization and redefining the relationships between the center and the periphery (Casini, 2016; Cammelli, 2015).

The regulatory intervention has had a wide impact on the museum sector, where the main measures include:

- the creation of a General Directorate for Museums (DGM);

- seventeen Regional Museum Centers;

- regional Secretariat;

- reduction of the number of Superintendencies;

- selection initial of 20 cultural institutes of I and II management level between museums and archaeological parks - extended subsequently to 32 with successive decrees (DM 44 of 23/01/2016) and dependent from the DGM and not more from the Superintendencies of belonging.

With reference to the museums designated as special autonomy, reference is made to a technical / organizational-scientific autonomy, the autonomy that in turn refers to L.352 / 97 „Provisions on cultural heritage" which initiated the first form of experimentation, which made the Superintendency of Pompeii autonomous.

For the museums, designated as such, the following has been envisaged: the redefinition of their organizational structure by expanding the functional areas; the establishment of the Board of Directors chaired by the director of the museum, the Scientific Committee and the Board of Auditors; the elaboration of a „reinforced” Statute (subject to approval), the only instrument of regulatory autonomy in the absence of regulatory capacity and making talk, in this respect, of ,autonomy retained” (Forte, 2015: 7). 
The form of management of state museums and of local institutions belongs to the budget assumes the exclusive nature of a document of planning and reporting of resources, a condition from which the so-called ,super museums" selected are currently excluded thanks to the autonomy. Autonomous museums are required to carry out an accounting report that shows "the planning and results of financial and accounting management of economic resources available to the museum ,", in compliance with the principles of publicity and transparency” (art.3 DM December 23, 2014).

Furthermore, in terms of resource management, one of the new features concerns the possibility of generating and managing one's own cash flows and reinvesting them in activities; redirecting only $20 \%$ of the revenues deriving from the ticketing and rents to a solidarity fund in compliance with the principle of equalization; facilitating the acquisition of donations, defining the ticketing parameters.

The studies about the reform of Ministry of Cultural Heritage in Italy has been analyzed according to many juridical perspectives (Pastori, 2015; Cammelli, 2016a, 2016b; Carmosino, 2016; Casini, 2016a, b, 2017) highlighting the structural changes introduced by the reform, the new features of text law and which kind of innovation and incertitude observed.

The management perspective has been introduced by the researchers to give evidence of the reforms' effects on the governance of the public cultural system. Marzano and Castellini (2018) use a network governance perspective to give evidence of the process of the decentralization finalized to grant the autonomy and to enforce the process of the exchange between public and private realities.

In 2018, after the conference in Rome at the MAXXI museum, it has been elaborated a report thanks to the contribution of some managers of the autonomous museums. This document represents a first summary and testimony of the management of the autonomous museums that introduce the critical issues that emerged during the beginning years of management (Barrera et al., 2018), such as no guidelines, paucity of human resources and specialized, restricted autonomy, and so on. Giusti (2018) aims to verify if the requirements of normative dispositions are really satisfied, recurring to the case study on the Gallerie Nazionali di Arte Antica of Rome.

In the analysis of reform is delineated the importance of the human resources (Zan et al., 2018) finalized to find a new approach for the management of human resources because around that there is the trouble on the low understanding of the notion of management.

\section{RESEARCH FRAMEWORK}

The study has as its reference universe the 32 museums involved in the MiBACT reform, which has led to the conferral of autonomy for them. From the sites of the museums, all the information and documentation developed in compliance with the requirements of accounting law have been extrapolated from the section on transparency. The documentation concerns the period 2015-2018 for 20 museums that obtained autonomy in 2014 and 2016-2018 for the remaining 12 structures that were affected by the subsequent decree 44/2016. The documents refer to the accounting period and not to the year of publication. 
According to the L.352/97 that regulates the autonomy, museums were asked to draw up economic-financial communication documents divided into budgets and final balances. The budget, with authorization, constitutes a limit to the expenditure commitments and is divided into:

1. Financial estimate;

2. A general overview of financial management;

3. Budget estimate.

These documents are followed by the Planning Report, the multi-year Report; the Demonstration Table of the presumed administrative result; the report of the board of auditors.

The documents of a final nature relating to the economic-financial management results are:

1. Budget account

2. Income statement

3. Balance sheet

4. Explanatory notes

The annexes to the general report are added to the production of these information documents: Administrative situation; the Management Report; the report of the board of auditors. These documents are selected and analyzed to detect the degree of completeness if present on the museums' websites.

\section{THE INTRODUCTION OF THE NEW ACCOUNTING SYSTEM IN MUSEUMS: ANALYSIS OF THE PUBLISHED DOCUMENTATION.}

Consultation on museum websites has made it possible to become aware of the documentation produced since the start of autonomy. Not all information relating to the pre-reform period can be found, as for state museums, in the absence of autonomy, the publication obligation did not apply. The analysis concerns two groups of museums, respectively those made autonomous in 2014 and 2016. The results refer to the economic-financial year and not to the year of publication.

As shown in Table (1), about the situation of the 20 museums (granted autonomy in 2014) during the first year of activity, not all museums have fully fulfilled the required accounting production. An unstable trend emerges that reveals the low degree of completeness of the documentation. In 2015 , only $60 \%$ completed a financial forecast plan, of which only $15 \%$ in accordance with the accounting harmonization standard. The figure falls further if we consider the elaboration of the management budget (45\%), economic (15\%), the multi-year budget is drawn up by $25 \%$ and only $5 \%$ reports the presumed administrative result.

In 2016, the situation improves, especially to the extent that, although not all the museums present the same documentation, there is an increase in the percentage of $15 \%$ of museums that begin to prepare the forecast documentation according to the obligation of harmonization. While the subsequent years record a percentage, decrease compared to the forecast budgets. With regard to the final accounting documents, excluding those for the 2018 year, it emerges that in the years 2015-2016 approximately 60\% provided the financial and management reporting, given that it is attested around 5\% for 2017. In 2018, after four years, the situation is not improving, because the number of documents contained on the website is still low and incomplete. Only half of the museums have produced the cash flow and financial statement, followed by $40 \%$ that have elaborated on the balance sheet. 
The documentation on the surveys on operating events is the one that has the highest degree of default in the four-year period considered, in fact the Income Statement and the Balance Sheet are only processed by $30 \%$ of the museums in 2015, by 35\% in 2016 and 2018 , and $5 \%$ in 2017, demonstrating the high level of variability.

Table 1. Forecasting documents_AUTONOMOUS MUSEUMS dpcm 171/2014

\begin{tabular}{|l|c|c|c|c|}
\hline Year & $\mathbf{2 0 1 5}$ & $\mathbf{2 0 1 6}$ & $\mathbf{2 0 1 7}$ & $\mathbf{2 0 1 8}$ \\
\hline Decisional financial estimate & $60 \%$ & $75 \%$ & $60 \%$ & $15 \%$ \\
\hline Budget Management & $45 \%$ & $75 \%$ & $70 \%$ & $35 \%$ \\
\hline Summary overview & $15 \%$ & $45 \%$ & $40 \%$ & $25 \%$ \\
\hline Budget Estimate & $10 \%$ & $30 \%$ & $50 \%$ & $40 \%$ \\
\hline Multi-year financial statements & $25 \%$ & $40 \%$ & $35 \%$ & $15 \%$ \\
\hline Forecast administrative result & $5 \%$ & $10 \%$ & $25 \%$ & $25 \%$ \\
\hline
\end{tabular}

Table 1.1. Reporting documents_AUTONOMOUS MUSEUMS dpcm 171/2014

\begin{tabular}{|l|c|c|c|c|}
\hline Year & $\mathbf{2 0 1 5}$ & $\mathbf{2 0 1 6}$ & $\mathbf{2 0 1 7}$ & $\mathbf{2 0 1 8}$ \\
\hline Cash flow statement & $55 \%$ & $60 \%$ & $5 \%$ & $55 \%$ \\
\hline Financial statement & $60 \%$ & $60 \%$ & $5 \%$ & $50 \%$ \\
\hline Income statement & $30 \%$ & $35 \%$ & $15 \%$ & $35 \%$ \\
\hline Balance sheet & $30 \%$ & $35 \%$ & $5 \%$ & $40 \%$ \\
\hline Explanatory note & $15 \%$ & $10 \%$ & $/$ & $10 \%$ \\
\hline Administrative situation & $35 \%$ & $35 \%$ & $5 \%$ & $25 \%$ \\
\hline Programmatic Report & $10 \%$ & $20 \%$ & $15 \%$ & $15 \%$ \\
\hline
\end{tabular}

Regarding the twelve museums that obtained autonomy with the 2016 DM (Tab. 2 and 2.1) a similar situation emerges for the museums involved in the first ,experimentation”. In fact, in 2016 only $50 \%$ presents the financial budget and $60 \%$ the management budget. Particular attention is to be paid to the fact that, despite the obligation, of that $50 \%$, as many as $42 \%$ did not adapt the writing of the budget to the accounting harmonization rules. Moreover, also for this second tranche of museums, we highlight how much the percentages with respect to the economic surveys are substantially low, surpassing by a little $40 \%$ of the museums involved.

Table 2 Forecasting documents_AUTONOMOUS MUSEUMS DM 44 del 23/01/2016

\begin{tabular}{|c|c|c|c|}
\hline Year & 2016 & 2017 & 2018 \\
\hline Decisional financial estimate & $50 \%$ & $67 \%$ & $25 \%$ \\
\hline Budget Management & $58 \%$ & $83 \%$ & $50 \%$ \\
\hline Summary overview & $17 \%$ & $42 \%$ & $17 \%$ \\
\hline Budget Estimate & $25 \%$ & $25 \%$ & $17 \%$ \\
\hline Multi-year financial statements & $8 \%$ & $33 \%$ & $25 \%$ \\
\hline Forecast administrative result & $17 \%$ & $33 \%$ & $25 \%$ \\
\hline
\end{tabular}

Table 2.1. Reporting documents_AUTONOMOUS MUSEUMS DM 44 del 23/01/2016

\begin{tabular}{|l|c|c|c|}
\hline Year & $\mathbf{2 0 1 6}$ & $\mathbf{2 0 1 7}$ & $\mathbf{2 0 1 8}$ \\
\hline Cash flow statement & $33 \%$ & $25 \%$ & $25 \%$ \\
\hline Financial statement & $42 \%$ & & $25 \%$ \\
\hline Income statement & $42 \%$ & $8 \%$ & $25 \%$ \\
\hline Balance sheet & $42 \%$ & $/$ & $8 \%$ \\
\hline Explanatory note & $17 \%$ & $8 \%$ & $8 \%$ \\
\hline Administrative situation & $25 \%$ & $/$ & $8 \%$ \\
\hline Programmatic Report & $17 \%$ & $25 \%$ & $/$ \\
\hline
\end{tabular}


As noted for the first part of the museums, the situation is the same. In this case, there are very few museums (only the $25 \%$ ) that have presented the cash flow, financial and income statement.

Table 3. Comparison forecasting documents_AUTONOMOUS MUSEUMS 2014 and 2016

\begin{tabular}{|l|c|c|}
\hline First Year of autonomy & Museums (2014) & Museums (2016) \\
\hline Decisional financial estimate & $60 \%$ & $50 \%$ \\
\hline Budget Management & $45 \%$ & $58 \%$ \\
\hline Summary overview & $15 \%$ & $17 \%$ \\
\hline Budget Estimate & $10 \%$ & $25 \%$ \\
\hline Multi-year financial statements & $25 \%$ & $8 \%$ \\
\hline Forecast administrative result & $5 \%$ & $17 \%$ \\
\hline
\end{tabular}

Table 4. Comparison reporting documents_AUTONOMOUS MUSEUMS 2014 and 2016

\begin{tabular}{|l|c|c|}
\hline First Year of autonomy & Museums (2014) & Museums (2016) \\
\hline Decisional financial estimate & $55 \%$ & $33 \%$ \\
\hline Budget Management & $60 \%$ & $42 \%$ \\
\hline Summary overview & $30 \%$ & $42 \%$ \\
\hline Budget Estimate & $30 \%$ & $42 \%$ \\
\hline Multi-year financial statements & $15 \%$ & $17 \%$ \\
\hline Forecast administrative result & $35 \%$ & $25 \%$ \\
\hline
\end{tabular}

Comparing the first year of autonomy for both categories of the museums (Tab. 3 and 4), the analysis permits us to observe that the situation is not changed. Rather, it looks worse despite the experience of the previous implementation of the Reform. But, if for the first year is expected a not totally uniformity, it could be considered negative to notice the same practice in 2018, after 5 and 3 years respectively from the status of autonomy.

\section{RESULTS}

The analysis of the accounting documents gives a panorama on the degree of compliance of the autonomous museums. From the analysis emerges many interesting results for the museums for which autonomy is introduced for the first time.

In general, there is a general state of non-compliance, which is evident from the consultation of forecast and final documents.

Meanwhile, comparing the documents of the museums, there is high variability and fragmentation compared to the documentation presented. Moreover, a positive data is related to a sufficient degree of adequacy to fulfillment for the financial decision-making and management budget (where with the exception of the first year of the start of the 2014 and 2016 autonomy, there is a slightly lower percentage).

Another element that underlines the paucity of a long-term vision is the lack of a multi-year vision that can be found in the low percentage of multi-year financial statements present.

Finally, for these museums, there is a low capacity to draw up a summary document, such as the general picture and the presumed result of administration, in relation to the forecast documents already prepared. 


\section{FINAL CONSIDERATIONS}

The present study represents an analysis proposal with respect to understanding the repercussions of autonomy within state museums, of which only an experiment for Special Superintendence had taken place in the past. At the start of the study, a low percentage of museums were found which following the formalities imposed by the Legislator, show complete accounting documentation. In response to the first research question, therefore, there is a low degree of compliance with the law. Further information that comes from the analysis of the presence of documentation shows how much museums are more fulfilling in preparing a financial budget and less the final balance sheet. In this way, museums can hardly take advantage of the advantages deriving from an accrual accounting that allows seeing the connection between the resources consumed and the results achieved.

The lack of attention to the fulfillment of the results involves multiple observations. The first concerns the evidence that, as noted for the other public administrations (Guthrie, 1998), also for the museums interested in the reform, there are difficulties in implementing changes as per legislation. This aspect, fundamentally, depends on the lack of introduction to the reform and changes taking place, as well as the shortage of preparation for the required changes.

Another consideration, that permits to read these results, consists in the presence of human resource able to manage compliance to the requests and the know-how able to manage the areas of economic autonomy, bringing to the attention its ,advantages” (Zan et a., 2018). Untrained human resources ready for the changes introduced, employees not aware of the advantage deriving from the use of accounting data implies a lack of understanding of the effects that autonomy can generate. (Mussari, 2011).

The level of the incompleteness of the obligations could bring out a poor propensity to monitor economic efficiency (Sibilio Parri, 2004), a phenomenon not new for this sector and in general for the public administration. In fact, there is the repetition, for the museum sector, of the same mechanisms, already occurred for the public administration sector with the introduction of reforms.

Finally, the level of compliance gives photography about the adaptation of autonomous museums to the new regulatory provisions, but the incompleteness of data could be linked to the feature of the public sector and to the presence of technical and organizational obstacles (Chatelain-Ponroy, 2001). Indeed, these obstacles are translated into the troubles due to the personnel policies and waiting for the turnover or insertion of new professional figures, lack of preparation and guide to the innovations introduced, the new accounting system not supported by ad adequate knowledge to recur them.

Future developments in the work could lead to an understanding of the reasons why museums are non-compliant and whether the accounting system is considered and used as an information tool for management purposes. The expected results would allow having a greater knowledge with respect to the link between autonomy and management in the cultural sector, in an attempt to understand if "some areas of autonomy are not fully understood in their innovative and/or exploited scope or, otherwise, are insufficient cultural and financial resources indispensable for this purpose ,(Mussari, 2001, p.20). 


\section{REFERENCES}

Barrera, P., Gennari Santoni, F., Felicori, M., Casini, L., \& Lampis, A. (2018). Musei autonomi e Sistema nazionale dei Musei: un primo bilancio di gestione. Economia della Cultura, 28(1-2), 227-248.

Bonini Baraldi, S., (2007). Management, beni culturali e pubblica amministrazione.

Bourdieu. P. 1992. Les règles de l'art: genèse et structure du champ littéraire. Paris: Minuit

Cammelli, M. (2016) a. L'avvio della riforma del Mibact: echi dalla periferia. Aedon, (1), 0-0.

Cammelli, M. (2016) b. Problemi, soluzioni, riforme. Aedon, (2), 0-0.

Cammelli, M., (2015). "The Picklock of the Cuts of Spending in the Reorganization of Mibact." Aedon (1):1-5.

Carmosino, C. (2016). Il completamento della riforma organizzativa del Mibact: i nuovi istituti autonomi e il rafforzamento dei poli museali. Aedon, (1), 0-0.

Casini, L. (2016) a. La riforma del Mibact tra mito e realtà. Aedon, (3), 0-0.

Casini, L. (2016) b. Ereditare il Futuro: Dilemmi sul Patrimonio Culturale, Bologna, Il Mulino.

Casini, L. (2017). Trasformazioni dello Stato e riforme nel settore dei beni culturali. Economia della Cultura, 27(3), 395-400.

Cepiku, D., Meneguzzo, M., \& Senese, M. (2008). Innovations in public management and governance in Italy. Roma: Aracne.

Chatelain-Ponroy, S. (2001). Management control and museums. International Journal of arts management, 38-47.

Chirieleison, C. (2002). La gestione strategica dei musei. Milano: Giuffrè.

Chirieleison, C., (1999). La valutazione delle performance nelle gestioni museali: problematiche operative e tecniche. Studi e note di economia, 1, 143-168.

Dainelli F. (2003). The accounting information system of museums http://ernest.hec.ca/video/ pedagogie/gestion_des_arts/AIMAC/2003/resources/pdf/C/C20_Dainelli.pdf

Del Sordo, C., Orelli, R. L., \& Pazzi, S. (2012). Modelli di gestione e sistemi informativi-contabili di biblioteche e musei. Economia Aziendale Online, 3(2), 191-212.

Donato, F., (2013). La crisi sprecata. Per una riforma dei modelli di governance e di management del patrimonio culturale italiano. Aracne editore.

Forte, P. (2015). The New State Museums: A First Step in the Right Direction. Aedon, (1), 0-0. Giusti, M. (2018). I musei autonomi: il caso delle Gallerie Nazionali di Arte Antica. Aedon, (1), 0-0.

Gori, E., \& Fissi, S. (2012). Dalla contabilità finanziaria ai risultati economico-patrimoniali nei musei pubblici: una proposta metodologica/From financial accounting to financial results in pubblic museums: a methodological framework. IL CAPITALE CULTURALE. Studies on the Value of Cultural Heritage, (6), 127-154.

Gstraunthaler, T., \& Piber, M. (2012). The Performance of Museums and Other Cultural Institutions: Numbers or Genuine Judgments? International Studies of Management \& Organization, 42(2), 29-42.

Guthrie, J., \& Parker, L. (1990). Public Sector Management and Challenge of Managerialism. Guthrie, Parker \& Shand.

Hood, C. (1991). A public management for all seasons? Public administration, 69(1), 3-19.

Marzano, M., \& Castellini, M. (2018). The Reform of the Italian Ministry of Cultural Heritage: Implications for Governance of the Museum System. The Journal of Arts Management, Law, and Society, 48(3), 206-220.

Migale L., (2001). Un bilancio per i musei. file://D:/user/Downloads/aspetti\%20economicoaziendali\%20dei\%20musei\%20(3).pdf

Mussari, R. (2011). Economia delle amministrazioni pubbliche. Milano: McGraw-Hill. 
Mussari, R. (Ed.). (2001). Manuale operativo per il controllo di gestione. Rubbettino Editore.

Osborne, David, and Ted Gaebler. 1992. Reinventing Government: How the Entrepreneurial Spirit Is Transforming the Public Sector. Reading, MA: Addison-Wesley.

Pangallozzi, M. C. (2019). L'istituzione museale: effetti e prospettive di una conquistata autonomia. Aedon, (1), 0-0.

Pastori, G. (2015). La riforma dell'amministrazione centrale del Mibact tra continuità e discontinuità. Aedon, (1), 0-0.

Paulus, O. (2003). Measuring museum performance: A study of museums in France and the United States. International journal of arts management, 50-63.

Pavan, A., \& Reginato, E. (2004). Programmazione e controllo nello Stato e nelle altre amministrazioni pubbliche: gestione per obiettivi e contabilità economica. Giuffrè.

Sibilio Parri, B. (2004). Quale bilancio per il museo. Misurare e comunicare i risultati.

Thompson, G. D. (2001). The impact of New Zealand's public sector accounting reforms on performance control in museums. Financial Accountability \& Management, 17(1), 5-21.

Turbide, J., \& Laurin, C. (2009). Performance measurement in the arts sector: the case of the performing arts. International journal of arts management, 56-70.

Zan, L. (2003 a). Autonomia, processi decisionali e controllo nelle istituzioni culturali. Economia della Cultura, 13(4), 465-476.Zan, L. (2003). Economia dei musei e retorica del management. Electa.

Zan, L. (Ed.). (1999). Conservazione e innovazione nei musei italiani: management e processi di cambiamento. Etas libri.

Zan, L., Baraldi, S. B., \& Santagati, M. E. (2018). Missing HRM: the original sin of museum reforms in Italy. Museum management and curatorship, 33(6), 530-545. 